\title{
Probing Coastal Eco-Tourism in Pasir Putih Beach, Indonesia
}

\author{
Hengky, S. H. \\ Shine Institute, Kent Polytechnic, University of Bina Darma, Indonesia \\ E-mail: hengky_halim@yahoo.com.au
}

Received: Dec. 17, 2016 Accepted: Jan. 9, 2017 Published: Jan. 15, 2017

doi:10.5296/bmh.v5i1.10606 URL: http://dx.doi.org/10.5296/bmh.v5i1.10606

\begin{abstract}
Indonesia's tourism-ministry is targeting 20 million foreign tourists' visiting Indonesia in 2019. Moreover, traveling to the natural-coastal eco-tourism becomes a tourist's trend and their priority's decision on considering their leisure time's plan. "Pasir Putih" beach is one of the natural beach-tourism, have been attractive natural-scenic in Lampung. The existing performance indicated that the destination is quite ordinary. Therefore, the visitation of tourist to Lampung increased averagely up to $30 \%$ annually. While, recently there has been some environmental quality problem such as a damage to coral reefs and sea grass beds around the destination. This lowers the quality to the environment in the future that will impact the quantities, and the visit of tourists. It is extremely clear visible in the results of gap analysis tourism performance bunch, who demonstrate the need for effort to control the utilization of the beach environment and implement programs for the coast protection of coastal areas for improving and maintaining its quality, which is very important, because such activity can provide economic contribution to the community and local government. Moreover, on the supply sides, travel agent collaborates with travel agency get to reduce the negative impact of coastal-tourism activity by conserving various coral reefs, sea grass. This effort would occur by developing local-community empowerment on conserving both sides of coastal-destination that becomes the favorites scenic for them on developing natural coastal tourism along the coastline.
\end{abstract}

Keywords: Coastal ecotourism, Tourist priority, Conserve, Economic 


\section{Introduction}

Central Statistics Agency (BPS) Lampung mentioned the number of foreign tourist, who visit and stay at various hotels and another accommodation in "Lampung" increased to $2.21 \%$. Furthermore, the number of tourists, who are visiting the destination increased 30\% annually. It followed by hotel growth rates increased to \$ 20 from the previous 2015 (Admin, 2016).

Moreover, Government of Lampung region launched a development program of tourism industry that includes: a) The development of tourism business of local-communities, b) simplify investment procedures for the tourism business, c) facilitating the development and improvement a regional labor force's skill on the field of travel, and d) encourage attitude / mental local people to be friendly towards tourists.

While a white-sand beach which is popular in exotic countries with high and challenging waves in the surf, travel agents and government need to improve infrastructure, including public facilities. Tourism promotion program in Lampung region ahead would be based on information technology. It may increase the number of tourists to Lampung from various domestic and unfamiliar countries. Development of the tourism sector in Lampung not only relies on the destination itself, but must present the convenience and comfort of ones traveled (Prakoso, 2016).

At the same time, a total of 8.36 million foreign tourists visited Indonesia from January to September 2016. That figure shows that international tourist arrivals grew by 8.5 percent compared with the same period last year. Furthermore, Indonesia's tourism-ministry is targeting 20 million foreign tourists' visiting Indonesia in 2019 (Budhiana, 2016). These study aims to respond to the target of Indonesian's tourism minister and to probe coastal eco-tourism gaps in Pasir Putih beach.

\section{Literature Review}

Beach tourism activity commonly utilized natural diversity resources along a border between land and sea environments, sun and sea, beach and beauty landscape, and good transportation infrastructure. Coastal-tourism include recreational activities involved tourists, who travel far away from where they live, and a little market that focused on beach and marine environment (coastal-zone). Eco-tourism activity concluded travel, and caring on environment by increasing travelers' knowledge about the fragility of the environment. The program would be conducted by introducing correlation between ecology and economy. In the form of cooperation between local community, local authorities, and tourists. This valuable information would support the program as well as enterprises engaged in tourism-business in a sustainable manner (Bjork, 2000).

Earlier research found that eco-tourism is activity trips to natural areas. While eco-tourist doing their activity, they care on reducing the negative environmental-impact. Besides, travel-agency and government aware on building environmental care, providing financial benefits to conservation, empowerment of local-communities, respect the local-culture, and supporting human rights (Buckley, Cater, Linsheng, \& Chen, 2008; Honey, 2008). 
Last years, Fitzgerald \& Stronza (2016) argued that implementing eco-tourism in one destination would protect people in some circumstances, but eventually tourism with animal habitats would make them vulnerable to poaching. They reminded mixed message to stakeholders on how importance real conservations are on protecting wildlife tourism. It would be on both distinction protected-areas and areas surrounding communities. Eco-tourism contributes to the preservation of the coastal landscape and alleviates poverty in underdeveloped areas of an economic development through a program of coastal-tourism in a sustainable and environment-based.

Tourism in the natural environment along the coastline is more directed at environmental-awareness namely coastal eco-tourism that characterized by marketing and managing destination to travelers and utilizing a resource without acknowledging any negative impact on natural-resources. Conserve coast-resources without acknowledging the regulation policy impact on protecting of travel agent and their clients. Both responses have failed to adequately consider about a long-term impact on environmental damage. Besides, visitors get experience on maintaining physical, social interaction and economic development for local people (Boley \& Green, 2016).

Eco-tourism planning in the 21st century, requires better coordination between the managers of natural resources and services of the tourism industry. Coordination will need based on a greater understanding between segments within the industry. Besides, it meets client's demand and their expectations of forthcoming possibilities. A change of perspective and priority will be needed by the tourism industry in general, by implementing natural resource management and by a specific eco-tourism operator, if the equipment of the future influx of visitors should be addressed (Ban \& Ramsaran, 2016; Conway \& Cawley, 2016).

However, eco-tourism used during this study is utilization and conservation of coastal-environments that minimize negative environmental impacts and implement aspects of learning on an ongoing basis. The coastal-tourism activity contributes to the economy of local communities both in the open and in the area of culture. Coastal eco-tourism is a traveling activity that attracted tourist and utilized the coastal-scenic. It's based on natural-landscaping and change of landscape opposite coast view and exploring scenery. The activity develops economics contribution to the local people who live closed to the beach, because they trained to utilize it in the natural way. Besides, the activity contributes funding to conserve the environment along the coastal-zone, and local-community empowerment (Ban \& Ramsaran, 2016; Conway \& Cawley, 2016; Fitzgerald \& Stronza, 2016; Boley \& Green, 2016, Halim, 2014; Buckley et al., 2008; and Khan, 2003).

\section{Methodology}

This one-year qualitative and quantitative study was conducted from October 2015-October 2016. The questionnaire was distributed to 250 respondents around Pasir Putih beach, Indonesia. It was collected by using a descriptive method that chosen by purposive and stratified sampling (Knotters 2010; Teddlie \& Yu, 2007; Ploeg, 1999). Data collected by triangulation techniques (Marwick \& Uniger, 1975): open observation, and structured interview. A respondent consists (Jenning, 2001): Association of travel agency, Department of 


\section{Macrothink}

Business and Management Horizons

ISSN 2326-0297

2017, Vol. 5, No. 1

Marine and Fisheries, Department of Culture and Tourism, Bureau of Statistics, Non-Government Organization, Association of Indonesian Hotels and Restaurants, domestic and international tourists, and local people along a coastline.

Data was tabulated by using a content analysis (Gottschalk, 2013; and Cohen, 1960) based on a coastal eco-tourism concept by exploring the parameter, posting each of its parameter, its frequency matched and counted. Finally result analyzed of the tabulated data (Smith, Scherre, \& Dowling, 2009; UNEP \& WTO, 2012). This study got Kappa value gaps by determining a current and expected performance of the destination (Henderson, 1991). The value was produced by specifying: the supply sides of a coast; set each parameter based on a concept; and established posting of each parameter based on its concept. Moreover, it needs assigned matched parameter based on frequency of each sub-concept. Besides, it counts repeated frequencies each parameter, which is expressed of each sub-concept, and finally, analyzed whole result.

\section{Results and Discussions}

As tabulation shows (Table 1), traveling to the natural coastal eco-tourism is the highest score of the stakeholder judgment. This finding appears to suggest that ordinary destination is the priority (Table 2). Nevertheless, let's to analyze the supply sides of "Pasir Putih" beach location is very easy to reach. The searcher can follow it by rising private car or public transportation. If searchers using personal, then it can start from City-Center Bandar Lampung travel time takes around several minutes. Meanwhile, if the searcher wants to use public transport, afterwards it could rise from Lampung straight to the Beach. Upon arriving at the location of the Beach, then searchers will be amazed by the scenery is very beautiful.

Table 1. Tabulated data of existing performance-ecotourism in Pasir Putih

\begin{tabular}{|l|l|l|}
\hline Existing Coastal ecotourism in Pasir Putih Beach & Value & \% Freq \\
\hline Travelling to coastal-ecotourism & 36 & 0.2590 \\
\hline Economics contribution & 26 & 0.1871 \\
\hline Utilized - in natural way & 23 & 0.1655 \\
\hline Conserve to the environment & 25 & 0.1799 \\
\hline Community empowerment & 29 & 0.2086 \\
\hline Kappa Coefficient $=\mathrm{K}=0.6043$ & 0.6043 & \\
\hline
\end{tabular}


Table 2. Tabulated data of expected performance -ecotourism in Pasir Putih

\begin{tabular}{|l|l|l|}
\hline Expected Coastal ecotourism in Pasir Putih Beach & Value & $\%$ Freq \\
\hline Travelling to coastal-ecotourism & 39 & 0.2393 \\
\hline Economics contribution & 30 & 0.1840 \\
\hline Utilized - in natural way & 29 & 0.1779 \\
\hline Conserve to the environment & 32 & 0.1963 \\
\hline Community empowerment & 33 & 0.2025 \\
\hline Kappa Coefficient $=\mathrm{K}=0.7087$ & 0.7087 & \\
\hline
\end{tabular}

The beach located in villages "Tarahan," South Lampung, a traveler can find attractive white-sand beaches without much effort or time consuming. The beach was beautiful and riveting. As in the Beach was greeted with incredible natural scenery. The combination of white sand and the trees waving blue sea, will make anyone amazed and stunned. "Lampung" does have many tourist destinations around the island and the beautiful beaches.

Even so, it does not have far to ride boats' typical of Lampung or speedboat, there is the beach is so close to Bandar Lampung. The beach has a bluish-green color that adds beautiful to visit and enjoy, in this place you can play sand, water play and sunbathing, and when holidays coming, this place a lot visited by tourists from all over the area. Sometimes, there is a foreign-tourist passing through this place just for enjoying a charm of white sand. Sunset in the beach was gorgeous. Its beauty is not inferior to other beaches in Indonesia. Sunset at White Sands as a sweet dessert after a long day on the beach.

Table 3. Performance gaps of coastal ecotourism in Pasir Putih

\begin{tabular}{|l|c|c|c|}
\hline Performance gaps-ecotourism in Pasir Putih Beach & Existing & Expected & Gaps \\
\hline Travelling to coastal-ecotourism & 0.2590 & 0.2393 & 0.0197 \\
\hline Economics contribution & 0.1871 & 0.1840 & 0.0031 \\
\hline Utilized - in natural way & 0.1655 & 0.1779 & -0.0124 \\
\hline Conserve to the environment & 0.1799 & 0.1963 & -0.0164 \\
\hline Community empowerment & 0.2086 & 0.2025 & 0.0061 \\
\hline Kappa Coefficient gaps = K gaps $=0.1044$ & 0.6043 & 0.7087 & 0.1044 \\
\hline
\end{tabular}

On the beach, there are so many travelers, who can perform a variety of tourist activities such as sunbathing. Sometimes they play on clean white sand or relax at a beach precisely. They can be enjoying the scenery around too. Nevertheless, if they missed all activities, they would be regret. It is just around the coast by renting a boat. And if they want to enjoy the scenic of a seaside, the beach is a very appropriate place. There are heterogeneous types of coral-reefs and ornamental fish presented around the island. They can enjoy the beauty of coral reefs and fish on this island by utilizing a box of glass, which is a tool that was traditionally used by 
people around for lobster and rock crab.

The tourists can spend time just to lie down, walk around or even look at the object to do around the beach. White and net beach, it will make the traveler feel at home to linger on this beach. For tourists who like the water sports, there are plenty of activities they can do at this beach. Some interesting activities such as swimming, canoeing and adventure with a fishing boat can do. First of all, it would attract (international) tourist and most of them visit the destination with their friend or family. They would spend the money that would strengthen local government income that supported conservation funding and its control by local community.

In addition, tourists can either explored the beach, and they can also rent a fishing boat to the island or sailing to Codong beach. Along the way, travelers will as well be presented as a view to the form of cage-mounted cages' fishermen to catch fish. A traveler can also do snorkeling activity there. This beach is already a community pride of Lampung. In fact, the place is not only popular with tourists within the country, but also foreign tourists (Carey, 2016).

The Beach has incredible scenery with a combination of seawater bluish green. Besides, it has a wonderful beach along the seashore that makes this one even more attractive. The atmosphere around this beach was also very shady, because there are a lot overgrown with trees, especially hibiscus tree. It would make the atmosphere not so hot when daytime, because travelers can take shelter underneath while they were enjoying views over the beach.

In terms coastal eco-tourism's performance gaps, tabulated data indicated that the value to existing destination's performance of Pasir Putih's beach. It is utilizing natural base trend (Table 3). According to the program of Lampung Government, who wants to increase tourist visitations, up to $30 \%$ annually, and it still had a handicapped about the gap of present traveling performance and their expectation (0.1044). Clearly, this study precisely indicated that expected-performance $(0.7087)$ is higher than current performance $(0.6043)$. The gap indicated that the government need more seriously on their conservation program to the coastal-environment. It is utilizing them in natural-ways as well as community empowerment becomes the first priority. It would be done by regional community empowerment program, especially on the social control of beach-tourism activity by tourist and stakeholder and follows by an economics contribution to the local people along the coastline and the supply of a natural-tourism. Besides, enhancing woman empowerment by developing small and medium enterprise would increase their individual economics.

Moreover, in terms of natural resources, Sea grass beds are marine plants that can adapt to the condition of sea water. Generally, they have grown up a substrate of fine sand-muddy. They live in a various place or types of seaweed, fish, mollusks, crustaceans. In addition; they also serve as a reducer of ocean currents and capture particles dissolved leading to the beach, grazing ground marine animals like Dugong sp, Eretmochelys Imbricata, spawning ground as Chelonia Mydas.

Furthermore, from the results of field-observations, coast's water was crowded with sea grass 
community. At this location, there were three species of sea-grass, which is of the type Enhalus sp, Thallasia sp, and Cymodocea sp, with index Varian Mean Ratio of 0.6778. It is indicating that sea grass communities within this area is scattered in random and uniform approach or spread evenly. This study found so many kinds of sea grass around the island such as Enhalus sp is the most dominant presence (Widodo, 2013).

A diversity of a mangrove in Lampung is low. They were dominated by Avicennia Alba and Avicennia Marina, on land that is newly formed. It was supported by Bruguiera Parviflora and Excoecaria Agallocha. Commonly, they were found in estuaries. Travelers can also find Nypa Fruticans, Sonneratia Caseolaris, and Xylocarpus Granatum, which show the influence of freshwater.

Coral reefs are colonies of small animals called polyps. These reef animals in symbiosis with algae called Zooxanthellae single cells form a reef building (CaCO3). They included in the Phylum Cnidaria, Scleractinia order ecosystems that have a high biological diversity and are divided into hard and soft corals. In Lampung, there are two types of the reefs, the fringing reef that is easily found on Lampung waters of the Gulf, the Strait of Sunda, Semaka Bay, West Coast, following the island and patchy. There are four formations of coral reefs: Atoll, fringing reef, barrier reef, and patch reef. Its function is as a drag abrasion and erosion on a beach from waves of sea water, shelter, spawning, rearing and foraging diverse marine life, fish, mollusks, echinoderm, which becomes a tourist attraction, sources used in medicine.

Besides the destruction of mangrove forests also resulted growing vulnerability of coastal areas in Indonesia to ebb. Mangrove well developed, will provide the functionality and great benefits both to support marine fishery's resources and aquaculture. It provides supply of building materials and other products as well as to protect the coast from the erosion threat. Sea grass and seaweed's habitat commonly provide ecological functions as coastal protection from waves and serve it as a natural filter that keeps water quality remains clear by depositing the material suspended from the mud on the mainland. Additionally, there is so many sea grass in the area of care for small fish and young turtles (hatchlings) newly hatched.

Exploitation of natural seaweeds made a negative impact to seaside environment precisely. It happened along the West Coast. It does not tend environmentally friendly, because of destructive harvesting methods to the bay's waters, especially it potentially utilized for mariculture (pearl and fish) covering 56,000 ha. From this potential, only 5,000 ha, they were awarded a concession of a foreign investment. They namely Hikari, Pty Ltd. Kyokko Shinju, Pty Ltd., and Mutiara Indah Lampung Pty Ltd. They produced each year of the three foreign-investment estimated to reach 500,000 pearls.

Grouper and other reef fish have not been cultivated optimally. So that development opportunities still open. Pilot projects cultivation duck and grouper Tiger grouper are being conducted between the Fisheries Department, Regional Development Planning Agency, Center for Marine Aquaculture and private in "Tanjung Putus" beach. However, there is still obstacles' Considerable technology in the province has 1.3 million ha of forest area, covering an area of 422500 ha (12.8\%) has been designated as a conservation area. 
Regarding conserved the coastal environment, the mangrove around the destination growth indicator not so significant. It influences the strength of under-sea or diving eco-tourism. It can be seen that most of the tourist like to watch variated mangrove with sea-fish, sea grass, and seaweed. This time the damage occurred in coastal-ecosystems along the white-sand beach such as predation and competition, mangroves, sea-grass beds, and coral reefs. Besides, there is a change in temperature of the sea-water, tides, over intensity of ultra violet, salinity, volcanic disturbances, and earthquakes.

Nevertheless, lots going over the mangrove forests into aquaculture area. Factually, mangrove forests serve to protect along the coastline from erosion is a good habitat for various species of sea fishes. The destruction of mangrove forests has resulted in fishermen have a fish with farther distances and increase their operational costs in the search for fresh fish. On the other hand, massive exploitation that occurred over the past has led in the development of ecological carrying capacity of areas exceeded, the negative impacts of resource exploitation directly affect the coastal -village communities. Public access to beach area was covered by a lot of developments in this region. The process of erosion of the coastline (erosion / abrasion) and grow shallow coastal waters or sedimentation, basically a process that occurs naturally.

A problem found throughout this study is exploitation of natural resources by interfering with a layout. It results from an observation which indicated that tourism activity has been made a limited facility and infrastructure into one obstacle on utilizing coastal-resources and tourism activity in the coastal-province of Lampung. The development pace improving a welfare of coastal-communities in Lampung closely linked to existence of infrastructure and facilities. It supports successfully business sector of the communities who have difficulty in terms of the accessibility by meaning transportation, other public infrastructure, and housing. Basic infrastructure facilities were needed by them to sustain smooth production and distribution of goods and services from and to the current areas. This is very important, because it is closely related to a movement of the wheels of economy in coastal-areas.

Other problems were found throughout this study is exploitation of natural resources, which interfere with a scenic layout. An observation result indicated that tourism activity has been made creating limited facilities and infrastructure into one of the obstacles in utilizing coastal-tourism resources in Lampung province. The pace of development would be improving the welfare of coastal-communities in Lampung closely linked to the existence of infrastructure and facilities. They supported successfully tourism business sector of the communities who have difficulty in terms of the accessibility by meaning transportation, other public infrastructure, and housing. Basic infrastructure facilities are needed by them to sustain the smooth production and distribution of goods and services from and to the current areas. This is very important because it is closely related to the movement of the wheels of economy in coastal-areas.

In terms of community empowerment, in the beach, there is also a unique souvenir seller's in "Lampung” which can be used as by searchers. Close to Beach, there are a variety of lodgings. The searchers do not need to worry, because the price offered is too diverse, and all of them depend on facilities that will be earned by the tourists during their stay. Live 
searchers choose according to the budget accommodation that searchers prepared.

"Lampung” unique-souvenir sellers also can be met around this beach. Tourists could be visiting on the beach without confused about it any longer. They had to find what a great souvenir to take home and given as presents to relatives at home. The beautiful coastal scenery visible in front of the eyes of one of them is the existence of some small islands around this beach which you can visit by renting a boat service (Rudianto, 2015).

\section{Conclusions}

These findings suggest that tourist's priority on considering their traveling to the coastal eco-tourism, is a natural coastal-tourism. On the other hand, on the supply sides, travel agent should be collaborated with travel agency. They get to reduce the negative impact of beach-tourism activity by conserving various coral reefs and sea grass. This effort would occur by developing local-community empowerment on conserving both sides of coastal-destination that becomes the favorites scenic for them by developing natural coastal tourism along the coastline.

At the same time, the government would be enhanced woman empowerment by creating small and medium enterprise. They created it to make local handicraft business and development. These activities would contribute economics to them.

However, natural destination along the coastline would attract (international) tourist, and most of them visit a natural-beach with their friend or family. They would spend their time and money that would strengthen local government's income. It would support their conservation funding precisely that control by local communities, who participates on coastal economic development (Wu \& Chen, 2016).

\section{Implications}

The local government gets to enhance their conservation-program and attracted travel agency. They should have made more their attention on conserving coastal-environment along the coastline to enhance the supply sides of the destination too.

At the same time, because of the limitation of time and funding, this study recommended more research on utilizing coastal and eco-tourism policy. It would be supported maintaining sustainable natural resources programs along the coastline.

\section{References}

Admin. (2016). Number of Travelers Lampung Rises 30 Percent Each Year, Lampung.com. [Online] Available: http://www.lampung1.com/2016/10/23/jumlah-wisatawan-lampung-meningkat-30-persen-seti ap-tahun/

Ban, J., \& Ramsaran, R. R. (2016). An Exploratory Examination of Service Quality Attributes in the Ecotourism Industry. Journal of Travel \& Tourism Marketing, 34(1), 132-148. http://dx.doi.org/10.1080/10548408.2016.1141155 
Bjork, D. P. (2000). Ecotourism from a conceptual perspective: An extended definition of a unique tourism form. International Journal of Tourism Research, 2(3), 189-202. https://doi.org/10.1002/(SICI)1522-1970(200005/06)2:3<189::AID-JTR195>3.0.CO;2-T

Budhiana, N. (2016). Ministry of Tourism of Indonesia chase Target 20 Million Foreign Tourists In 2019, Tempo.co. [Online] Available: https://bisnis.tempo.co/read/news/2016/09/28/090808111/kemenpar-kejar-target-20-juta-wisa tawan-asing-pada-2019

Buckley, R., Cater, C., Linsheng, Z., \& Chen, T. (2008). Shengtai Luyou: Cross-Cultural Comparison in Ecotourism. Annals of Tourism Research, 35(4), 945-968. http://dx.doi.org/10.1016/j.annals.2008.07.002

Boley, B. B., \& Green, G. T. (2016). Ecotourism and natural resource conservation: the "potential" for a sustainable symbiotic relationship. Journal of Ecotourism, 15(2), 122-138. http://dx.doi.org/10.1080/14724049.2015.1094080

Cohen, J. (1960). A Coefficient of Agreement for Nominal Scales. Educational and Psychological Measurement. [Online] Available: http://www.gsu.edu.html

Conway, T., \& Cawley, M. (2016). Defining ecotourism: evidence of provider perspectives from an emerging area. Journal of Ecotourism, 15(2), 122-138. http://dx.doi.org/10.1080/14724049.2016.1153105

Fitzgerald, L. A., \& Stronza, A. L. (2016). In Defense of the Ecotourism Shield: A Response to Geffroy et al. Trends in Ecology \& Evolution, 31(2), 94-95. http://dx.doi.org/10.1016/j.tree.2015.11.002

Gottschalk, L. A. (2013). Content Analysis of Verbal Behavior: New Findings and Clinical Applications (pp. 19-22). London: Routledge.

Halim, H. S. (2014). Excogitated Coastal Tourism Competitiveness by Implementing Eco-tourism in Anyer, Banten, Indonesia. International Journal of Marines Science, 4(7), 74-81. https://doi.org/10.5376/ijms.2014.04.0007

Henderson, K. (1991). Dimensions of Choice: A Qualitative Approach to Recreation, Parks, and Leisure Research. Venture (pp. 30-35). State College. Australia.

Honey, M. (2008). Ecotourism and Sustainable Development, Second Edition: Who Owns Paradise? (pp. 28-33). Washington, D.C.: Island Press.

Jenning, G. (2001). Tourism Research (pp. 136-152). John Willey \& Sons Australia, Ltd.

Khan, M. (2003). ECOSERV: Ecotourists' Quality Expectations. Annals of Tourism Research, 30(1), 109-124. http://dx.doi.org/10.1016/S0160-7383(02)00032-4

Knotters, M., \& Brus D. J. (2013). Purposive versus random sampling for map validation: a case study on ecotope maps of floodplains in the Netherlands. Ecohydrol, 6, 425-434. http://dx.doi.org/10.1002/eco.1289 


\section{Macrothink}

Business and Management Horizons

ISSN 2326-0297

2017, Vol. 5, No. 1

Marimin. (2010). Teknik dan Aplikasi Pengambilan Keputusan Kriteria Majemuk (pp. 24-28). Jakarta: Grasindo.

Marwick, D. P., \& Uniger, C. H. (1975). The Sample Survey, Theory and Practice. New York: Mc Graw Hill Book Co.

Ploeg, J. (1999). Identifying the best research design to fit the question, Part 2: qualitative designs, Evid. Nased Nurs, 2, 36-37. http://dx.doi.org/10.1136/ebn.2.2.36

Prakoso, J. R. (2016). Besides Pahawang, Lampung Also Have the White Sand Beach, detik.com.

[Online]

Available:

http://travel.detik.com/read/2016/04/26/135043/3196895/1519/selain-pahawang-lampung-jug a-punya-pantai-pasir-putih

Rudianto, E. (2015). White Sand Beach Lampung, Ragam Wisata. [Online] Available: http://ragamwisataid.blogspot.com/2015/08/pantai-pasir-putih-lampung.html

Smith, A. J., Scherre P., \& Dowling, R. (2009). Impacts on Aboriginal spirituality and culture from tourism in the coastal waterways of Kimberly region, North West Australia. Journal of Ecotourism, 8(2), 82-98. http://dx.doi.org/10.1080/14724040802696007

Teddlie, C., \& Yu, F. (2007). Mixed methods sampling, A typology with examples. Journal of Mixed Methods Research, 1, 77-100. http://dx.doi.org/10.1177/2345678906292430

UNEP \& WTO. (2012). Tourism in the Green Economy-Background Report, United Nations Environment Programme and World Tourism Organization, UNWTO, Madrid.

Wu, S., \& Chen, Y. (2016). Local intentions to participate in ecotourism development in Taiwan's Atayal communities. Journal of Tourism and Cultural Change, 1-22. http://dx.doi.org/10.1080/14766825.2016.1253705

Widodo, S. (2013). About Coastal Lampung. Coastal Environment of Lampung Province. [Online]

Available:

https://fdwiagungwidodo.wordpress.com/2013/01/17/lingkungan-pesisir-provinsi-lampung/

\section{Copyright Disclaimer}

Copyright for this article is retained by the author(s), with first publication rights granted to the journal.

This is an open-access article distributed under the terms and conditions of the Creative Commons Attribution license (http://creativecommons.org/licenses/by/3.0/). 